\title{
16 Participatory evaluation of mobile tree nursery
}

\author{
Abate Tsegaye, Elias Cherenet and \\ Hadera Kahesay
}

\section{Introduction}

Tree nurseries vary greatly from a few dozen seedlings grown in household nurseries to mechanized commercial enterprises producing millions of seedlings per year. Household nurseries are established and managed by individual farmers and/or their families to meet the family's need for tree seedlings; they may also generate income through selling seedlings. Furthermore, seedlings may be provided to community members to enhance local relationships and social capital (Roshetko et al., 2010).

The establishment of permanent and high capacity nurseries requires initial high investment, utilizes the land permanently and is labour intensive. Fencing, land preparation and installation of irrigation systems are some of the activities needed to establish a permanent forest tree and shrub nursery: mobile nurseries may help to avoid these issues. In addition, farmers can transport mobile nurseries with small quantities of seedlings on their shoulders or back, or by donkey or horse.

Nursery production is a seasonal activity and seedling numbers will vary considerably depending on the forest development project. Flexible, easily manageable and effective nurseries are important to fulfil the demand at household level and encourage forest development that will contribute to preventing land degradation and help to mitigate the effects of climate change. Nursery practices may be carried out in the morning or evening in conjunction with animal management activities, contributing to more efficient household labour. Thus, mobile nurseries made from locally available material could circumvent the need for high cost permanent nurseries as well as reduce the costs of household labour.

\section{Aims and objectives}

The aim of this study was to introduce mobile tree nurseries into a community in the Ethiopian highlands, evaluate their economic feasibility and advantage over permanent nurseries and assess their socio-economic impact in terms of rural livelihood improvement. 
The specific objectives were to:

- $\quad$ evaluate and introduce a model mobile tree nursery using wooden boxes;

- assess the socio-economic contribution of mobile nurseries in rural livelihood improvement.

\section{Materials and methods}

The study was conducted in the Gumara-Maksegnit watershed, Gondar Zuria district, Ethiopia, located between $12^{\circ} 24^{\prime}$ and $12^{\circ} 31^{\prime}$ latitude and $37^{\circ} 33^{\prime}$ and $37^{\circ} 37^{\prime}$ longitude (Kibruyesfa, 2011). The watershed lies in the upper part of the Lake Tana basin in north-west Ethiopia and drains into the GumaraMaksegnit river, which ultimately reaches Lake Tana.

A farmers' research group (FRG) comprising ten interested members (eight women and two men) was established in 2011. The FR G members, development agents of peasant associations and district natural resource management experts, were trained in using mobile nurseries and other nursery operations. The mobile nurseries consisted of $1.2 \mathrm{~m} \times 0.8 \mathrm{~m}$ bamboo and wooden boxes capable of accommodating up to 369 seedlings in $5.1 \mathrm{~cm}$ diameter polythene tubes. The boxes were set above the ground to allow the roots to be pruned as they emerged from the bottom of the pots. Farmers were advised to use sand, manure and topsoil mixture in 1:2:3 ratios for potting, and to maintain the boxes for continuous use over many years. Following the training, farmers prepared different soils for potting and they were advised on how to mix soils.

Later on, mobile nursery coordinators were provided with polythene tubes and the seeds of Cordia africana, Rhamnus prinoides, Eucalyptus camaldulnesis, Eucalyptus saligna and Olea europaea. Each FRG member took polythene tubes in proportion to the number of seeds they wanted to sow; they were also free to choose seeds of trees based on their preferences. FRGs were assisted at the time of sowing and the expected date of germination. After this, FRGs were regularly visited up to the time of hardening of seedlings and plantation. Finally, for economic assessment all materials and efforts used for nursery management were estimated while the current market price of each type of seedling was recorded. In 2012, FRGs were given refresher training and also asked to look for other seedlings they wanted to raise. The other procedures followed were the same as for 2011 .

\section{Results and discussion}

In 2011, FRG members raised seeds of Cordia africana, Rhamnus prinoides, Eucalyptus camaldulnesis, Eucalyptus saligna and Olea europaea based on their preferences. FRG members' seed preferences depended on seedling market value, the tree types they wanted to plant and the environmental adaptability of tree species. In 2011 FRG members earned Ethiopian birr (ETB) 100 to 
Table 16.1 Birr gained by selling seedlings raised in bamboo box

\begin{tabular}{rlll}
\hline No. & Name of FREG & $2011(2003)$ & 2012 (2004) \\
\hline & & Total birr gained & Total birr gained \\
\hline 1 & Menigst Wondaya & 400.00 & - \\
2 & Misganawu Yigzawu & 325.00 & 65.00 \\
3 & Gebaye Abebe & 120.00 & - \\
4 & Gbaye Degu & 100.00 & - \\
5 & Yeshimebete Awoqe & 100.00 & 200.00 \\
6 & Teref Tegegne & 145 seedling plant & 150 seedling for planting \\
7 & Zewalu Nega & 200.00 & 150.00 \\
8 & Azeneg Alemu & 100.00 & 215.00 \\
9 & Amisal Mezigebu & Not available & - \\
10 & Talem Tesie & 150 seedling plant & - \\
& Total & 1345.00 & 630.00 \\
\hline
\end{tabular}

ETB 400 from sales of the seedlings (Table 16.1). In addition to the extra income the farmers generated, the new practice brought a paradigm shift in tree planting in the area.

In 2012, farmers selected seeds and grew tree seedlings based on their experiences in the previous year (Figure 16.1). In 2012, farmers collectively sowed 1,110 Olea europaea and 1,177 Rhamnus prinoides seeds from the same seed pool as in the previous year, as well as thirty seeds of the afttit tree. Seed germination was successful; however due to lack of proper management, half the FRG members lost all their seedlings due to attack by rodents.

It was found that the FRG members who avoided rodent attack did so with management strategies such as moving the box from place to place and raising them further from the ground. Some FRG members who lost their seedlings due to rodent attack re-sowed with 451 seeds of Eucalyptus camaldulnesis and 44 of Cordia africana. At the end of the season, from the total seedlings sown, 812 were suitable for sale and planting out (Table 16.2).
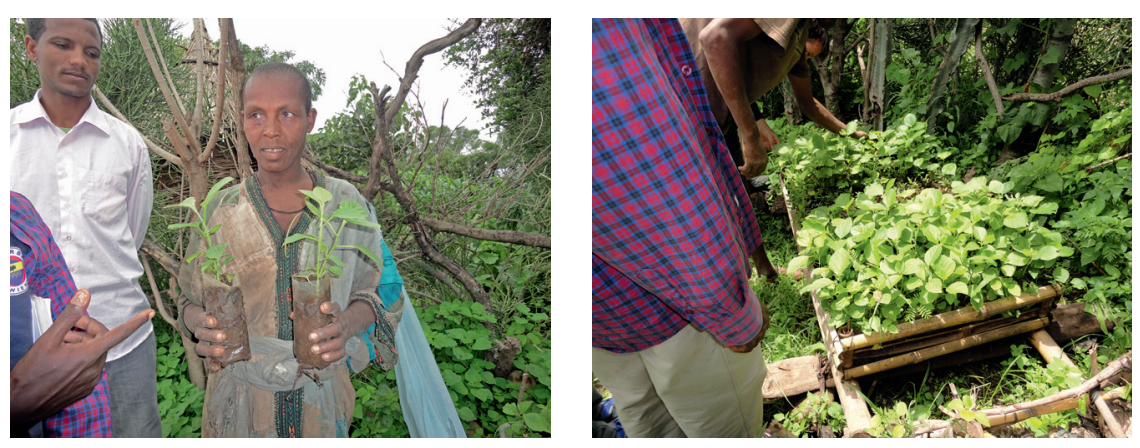

Figure 16.1 Mobile tree nursery implemented and managed by women 
Table 16.2 Number of seeds sown, seedlings remaining after rodent damage and seeds re-sown in 2012

\begin{tabular}{|c|c|c|c|c|c|c|}
\hline \multirow[t]{3}{*}{ Name of FRG member } & \multicolumn{4}{|c|}{ Tree species } & \multirow[b]{3}{*}{$\begin{array}{l}\text { Seeds } \\
\text { re-sown }\end{array}$} & \multirow[b]{3}{*}{ Total } \\
\hline & \multicolumn{2}{|c|}{ Olea europaea } & \multicolumn{2}{|c|}{ Rhamnus prinoides } & & \\
\hline & $\begin{array}{l}\text { Seeds } \\
\text { sown }\end{array}$ & $\begin{array}{l}\text { Seedlings } \\
\text { raised }\end{array}$ & & $\begin{array}{l}\text { Seedlings } \\
\text { raised }\end{array}$ & & \\
\hline Menigst Wondaya & - & & 320 & & & 320 \\
\hline Misganawu Yigzawu & 210 & 27 & 496 & 22 & $251 \star$ & 496 \\
\hline Gebaye Abebe & 100 & & 180 & & & 180 \\
\hline Gbaye Degu & 100 & 42 & 190 & 4 & $2 \star \star$ & 190 \\
\hline Yeshimebete Awoqe & 100 & 110 & 180 & 5 & & 180 \\
\hline Teref Tegegne & 100 & & 185 & & $200 \star$ & 185 \\
\hline Zewalu Nega & 150 & 10 & 200 & 39 & $16^{\star \star}$ & 200 \\
\hline Azeneg Alemu & 100 & 58 & 196 & & $26 \star \star$ & 196 \\
\hline Amisal Mezigebu & 150 & & 50 & & & 200 \\
\hline Talem Tesie & 100 & & 40 & & & 170 \\
\hline Total & 1110 & 247 & 1177 & 70 & 812 & 2317 \\
\hline
\end{tabular}

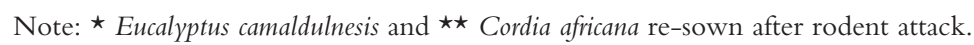

In a group discussion, FRG members confirmed that other than rodent attacks they did not observe any other problems or losses due to diseases or pests, whereas two FRG members lost their entire planting of 7,400 Eucalyptus camaldulnesis seedlings in ordinary nurseries due to termites. Thus, farmers appreciated and agreed that mobile tree nurseries were beneficial for avoiding seedling losses to rodents and termites due to the ability to isolate the seedlings from the pests. The species preference of the FRG members in both years was ranked as Rhamnus prinoides, Eucalyptus camaldulnesis, Olea europaea subsp and Cordia africana. The first two species were preferred for their high market value.

The main costs were purchasing bamboo boxes and the polythene tubes. In addition, nursery management costs included watering, weeding, box rotation, fencing and mulching materials and management practices. For instance, farmers water seedlings early in the morning and/or in the evening. The average time it took to fetch water from the nearby river for watering seedlings was up to 40 minutes (Table 16.3). Thus, income statement of this project was done based on investment cost (Table 16.4) and revenue generated (Table 16.5).

Table 16.6 shows the net income/loss of the project. In 2011 a net income of ETB 1,077.50 was achieved whereas in the year 2012, a net income of ETB 132.50 was obtained. The net income in 2012 was lower due to a severe rodent attack on seedlings raised after a long dry spell. Farmers stressed that as well as raising seedlings for income generation, mobile tree nurseries motivated them to plant trees in their area. With mobile tree nurseries, seedlings can be transported easily to the planting site. This motivates community seedling raising, particularly among women. Therefore, the cost-benefit analysis results show that the introduction of mobile nurseries is economically justifiable. 
Table 16.3 Miscellaneous costs

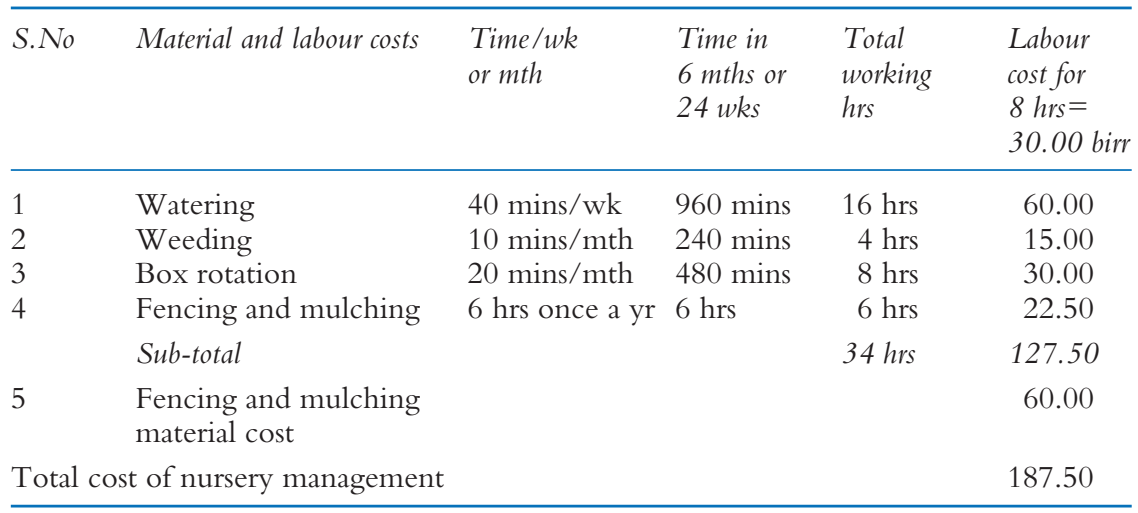

Table 16.4 Investment costs

\begin{tabular}{lcrll}
\hline Types of material & Quantity & Unit cost & $\begin{array}{l}\text { Total cost of } \\
\text { material }\end{array}$ & $\begin{array}{l}\text { Minimum expected use } \\
\text { time duration }\end{array}$ \\
\hline Bamboo box & 10 & 150.00 & 1500.00 & $\begin{array}{l}5 \text { years } \\
\text { Polythene tube }\end{array}$ \\
$\begin{array}{l}\text { Total investment cost } \\
\quad \text { (TIC) }\end{array}$ & & 400.00 & $\begin{array}{l}5 \text { years } \\
5 \text { years }\end{array}$ \\
$\begin{array}{l}\text { Depreciation cost } \\
\begin{array}{l}\text { Miscellaneous cost of } \\
\text { each year }\end{array}\end{array}$ & 1900.00 & TIC/5years \\
Total cost in year 2011-12 & 380.00 & for details see \\
\hline
\end{tabular}

Table 16.5 Revenues generated

\begin{tabular}{|c|c|c|c|}
\hline \multirow[t]{2}{*}{ Item } & \multicolumn{2}{|c|}{ Total amount of birr generated } & \multirow[t]{2}{*}{ Valuation } \\
\hline & Year 2011 & Year 2012 & \\
\hline $\begin{array}{l}\text { Selling of } \\
\text { seedling }\end{array}$ & 1345.00 & 630.00 & \\
\hline Planting & $\begin{array}{l}\text { E. camaldulnesis }=200 \\
\text { C. africana }=198 \\
\text { O. europaea subsp. }=10\end{array}$ & $\begin{array}{l}R . \text { prinoides }=10 \\
\text { E. camaldulnesis }=150\end{array}$ & $\begin{array}{l}3 \text { E. camaldulnesis }=1.00 \\
1 \text { R. prinoides }=2.00 \\
1 \text { O. } \text { europaea subsp. }=2.50 \\
1 \text { C. } \text { Africana }=1.00\end{array}$ \\
\hline $\begin{array}{l}\text { Value of } \\
\text { planting }\end{array}$ & 300.00 & 70.00 & \\
\hline $\begin{array}{l}\text { Total } \\
\text { revenue }\end{array}$ & 1645.00 & 700.00 & \\
\hline
\end{tabular}


Table 16.6 Trends of cost-benefit analysis

\begin{tabular}{|c|c|c|c|c|c|c|}
\hline \multirow[t]{2}{*}{ Item } & \multicolumn{5}{|c|}{ Years (in each year total revenue increase by $10 \%$ ) } & \multirow[t]{2}{*}{ Remark } \\
\hline & 2011 & 2012 & 2013 & 2014 & 2015 & \\
\hline Total revenue & 1645.00 & 700.00 & $2171.00 \star$ & $2388.00 \star$ & $2627.00^{\star}$ & $\begin{array}{l}\text { * Revenues } \\
\text { expected }\end{array}$ \\
\hline Total expense & 567.50 & 567.50 & & & & \\
\hline Net income/loss & 1077.50 & 132.50 & & & & \\
\hline
\end{tabular}

\section{Conclusions and recommendations}

FRG members found the mobile tree nursery technology to be viable due to its portability and very important due to its financial benefits, potential to create opportunities for women and its ecological importance. The economic evaluation showed it is feasible to replicate and scale up the technology; however, it will be necessary to take measures for the prevention of attack by rodents. Of the tree species trialled, Rhamnus prinoides, Eucalyptus camaldulnesis, Olea europaea subsp and Cordia africana were the preferred species in decreasing order. Participants also confirmed their positive motivation towards taking up the technology.

This study recommends that Government and other stakeholders invest in scaling-up and scaling-out the technology along with further studies on how to prevent attacks by rodents and other potential pests and diseases.

\section{Acknowledgement}

Our deepest gratitude goes to the International Center for Agricultural Research in the Dry Areas (ICARDA) project for financial support. This research was conducted within the framework of the Amhara Region Agricultural Research Institute under the Gondar Agricultural Research Center. The Institute as well as the Center are both cordially acknowledged. Last, but not least, we extend our appreciation to the participant farmers and woreda experts for their efforts.

\section{References}

Kibruyesfa, S., 2011. 'Assessment of Forest Cover Change and Its Environmental Impacts Using Multi-Temporal and Multi-Spectral Satellite Images: The Case of GumaraMaksegnit Watershed of North Gondar Zone, Ethiopia'. MSc thesis, Wondo Genet College of Forestry, Hawass University, Shahemene, Ethiopia.

Roshetko, J.M., Tolentino Jr., E.L., Carandang, W.M., Bertomeu, M., Tabbada, A., Manurung, G.E.S. and Yao, C.E., 2010. 'Tree Nursery Sourcebook - Options in Support of Sustainable Development'. World Agroforestry Centre (ICRAF) and Winrock International, Bogor, Indonesia.

Worku, Y., Alem, T., Yeshanew, A., Abegaz, S., Kinde, H., Getinet, A., 2010. 'Socioeconomic survey of Gumara-Maksegnit watershed'. ICARDA-ARARI-EIAR-BOKUSG-2000 project and Gondar Agricultural Research Center, Ethiopia. 